\title{
Nursing and Epidemiology
}

\author{
Yi Sung Eun* \\ Aram Nightingale Nursing Institute, Republic of Korea
}

Received: June 18, 2018; Published: June 26, 2018

*Corresponding author: Yi Sung Eun, Aram Nightingale Nursing Institute, 206-1604 Raemianhurest, 860 Hoguk-ro, Dukyang-gu, Goyang-si, Gyunggido 10467, Republic of Korea

\section{Opinion}

The definition of epidemiology is "describing the characteristic of health problem and physiological change of human, identifying the cause of health problem, developing the method to decrease health problem"[1]. The term 'epidemic' was originated from the book of Hippocrates. With the development of philosophy of science, Positivism and Empiricism after Renaissance, the way and method to identify cause of health problem was searched and evaluated by many scholars; John Snow, F. Nightingale, W. Farr and many microbiologists. In the early of 20C, epidemiology has been developed in USA with the support of pragmatism and the social need. John Snow, the father of classical epidemiology, identified the source of cholera and the way of eradicate cholera without microbiological knowledge. Only with observation and logical thinking, he could save the lives of London people from the outbreak of infectious disease in 1848-1854. Nursing is the art and science to be with the person of distorted life [2]. Observation is the one of main approaches to care people in nursing. Observation is the basic way getting data in epidemiological research. With epidemiological research, Nursing can develop many strategies to care health problems.

\section{Nursing \& Epidemiological Research}

As well known, F. Nightingale set the basis of modern nursing. F. Nightingale conducted some important epidemiological research. The first study was the hospital mortality study conducted in 1861. F. Nightingale's second epidemiological study was the nurse mortality study. She compared mortality rate of hospital nurses with that of London women, and identified the risk of infectious disease in nurse's death [3]. The action and role of infection control nursing is based on epidemiological research. The knowledge for surveillance and identify the cause of infection is adopted from the basis of epidemiology as F. Nightingale did. Occupational health nursing, school health nursing and public health nursing are the areas which need apply the knowledge of epidemiology to improve the context of nursing action. Occupational health nurse must pay more attention to the change of worker's physiological condition and new type of health signs with epidemiological mind. School health nurse must also pay attention to the illness and absence pattern of stu dents with epidemiological mind. The epidemiological research will be the stairs and elevators to develop and improve nursing practices. However, it will be necessary for nurses to be alerted and activated with philosophical mind and logical practice.

\section{For the Future}

In 2007, the Nationwide Survey on the prevalence of Parkinson's disease in South Korea was conducted. The survey was sponsored by Korean Center for Disease Control (KCDC). The study was planned in 3 steps; National Health Insurance data analysis, the hospital data survey and the community survey. In the study design, the community survey was a supplementary step of the study. The nursing students of Kwandong University were the surveyors to collect data for the community study. The outcome of the community survey showed such a good result, and the next step survey; that was the hospital survey, was cancelled. Because of the outcome through community study can cover the purpose of the hospital survey [4].

This episode shows that nursing science can do an important role in disease prevalence and incidence study. And it is necessary for nurse researcher to have profound knowledge on epidemiology. Evidence based nursing practice is the area to adopt the knowledge of epidemiology. According to the definition of causal relationship by McMahon, the strength of statistical significance could be one of the factors making decision [5]. However, it could be dangerous to make decision based only the result of statistical relationship. It is the time to pay more attention to Peirse's pragmatism [6], which is focusing on the decision based in human life.

\section{References}

1. Kim, Jung Soon. The Principles of Epidemiology ( $1^{\text {st }}$ Edn.) Shinkwang publishing, Seoul, P. 10.

2. Choi, Nam Hee. The Nature of Nursing. Seoul Narrative Institute, Seoul.

3. F Nightingale (1863) Notes on Hospitals ( $3^{\text {rd }}$ Edn.) London, p. 21.

4. Jung, Hae Kwan Lee, Jong Shik Yi, Sung Eun Kim, Yang Ho (2007) The Nationwide Survey on the Prevalence of Parkison's Disease. Sungkyunkwan University \& KCDC, p. 31. 
5. Kim, Jung Soon The Principles of Epidemiology. (1 ${ }^{\text {st }}$ Edn.) Shinkwang publishing. Seoul, p.31.

\section{(C) (P) This work is licensed under Creative}

Submission Link: https://biomedres.us/submit-manuscript.php
6. Charles S Peirce (2005) Pragmaticism, translated by Hung HC, Chunggae, Seoul.

$\begin{array}{ll}\text { BIOMEDICAL } & \text { Assets of Publishing with us } \\ \text { RESEARCHES } & \text { - Global archiving of articles } \\ & \text { - Immediate, unrestricted online access } \\ & \text { - Rigorous Peer Review Process } \\ & \text { - Authors Retain Copyrights } \\ & \end{array}$

